\title{
NOP10 Gene Mutation
}

National Cancer Institute

\section{Source}

National Cancer Institute. NOP10 Gene Mutation. NCI Thesaurus. Code C152081.

A change in the nucleotide sequence of the NOP10 gene. 